\title{
Identification of surface-associated proteins of Bifidobacterium animalis ssp. lactis KLDS 2.0603 by enzymatic shaving
}

\author{
Dequan Zhu, ${ }^{\dagger} † \ddagger$ Yu Sun, ${ }^{*} \dagger$ Fei Liu, ${ }^{*} \dagger$ Aili Li, ${ }^{*} \dagger$ Limei Yang, ${ }^{*} \dagger$ and Xiang-Chen Meng ${ }^{*}{ }^{1}$ \\ *Key Laboratory of Dairy Science, Ministry of Education, and \\ †Synergetic Innovation Center of Food Safety and Nutrition, Northeast Agricultural University, Harbin 150030, People's Republic of China \\ $\ddagger$ College of Life Sciences, Jiamusi University, Jiamusi 154007, People’s Republic of China
}

\section{ABSTRACT}

Bifidobacteria are commensal microorganisms of the human and animal intestinal tract, and their surface proteins can mediate bacterial communication and chemical sensing in the environment, as well as facilitate interactions between bacteria and the host. However, a systematic study of the outer surfaceassociated proteome of bifidobacteria has not been undertaken. In the present study, the proteins located on the surface of Bifidobacterium animalis ssp. lactis KLDS 2.0603 were systematically identified by a nongel proteomic approach, which consisted of the shaving of the bacterial surface with trypsin and an analysis of the released peptides by liquid chromatography-tandem mass spectrometry. A total of 105 surface-associated proteins were found, of which 15 proteins could potentially be involved in adhesion and interactions between bifidobacteria and the host. The proteins related to adhesion and interaction between bacteria and the host include pilus structure proteins (Fim A, Fim B), 10 moonlighting proteins, an NLP/P60 family protein, an immunogenic secreted protein, and a putative sugarbinding secreted protein. The results provide the basis for future studies on the molecular mechanisms of the interactions between bifidobacteria and the host.

Key words: probiotics, surface proteins, shotgun proteomics, interaction between probiotics and host

\section{INTRODUCTION}

Probiotics are defined as live microorganisms that confer a health benefit on the host when consumed in adequate amounts. Health benefits conferred by probiotics may include modulating intestinal microflora (Marteau et al., 2002; Ouwehand et al., 2002), suppress-

Received October 30, 2015.

Accepted January 21, 2016.

${ }^{1}$ Corresponding author: xchmeng@hotmail.com ing pathogens (Shah, 2000; Shiby and Mishra, 2013), alleviating diarrhea, improving lactose metabolism (Jiang et al., 1996; Martini et al., 1991), antimutagenic and anticancer properties, reducing the level of serum cholesterol, treating inflammatory bowel disease, and stimulating the immune system. Species of the Lactobacillus and Bifidobacterium genera are mainly considered probiotics. Bifidobacteria are commensal microorganisms of the human and animal intestinal tract, which are potential probiotic microorganisms that contribute to the health of the host.

To exert their functions, probiotic strains must be able to adhere to and colonize the host's intestinal tract (González-Rodríguez et al., 2013; Wang et al., 2013). Therefore, one important criterion for probiotic characterization is the ability to adhere to epithelial cells of the intestinal tract. Adhesion to the gut is believed to be mediated by adhesive factors, including lipoteichoic acids, carbohydrates, and proteins located on the outer surface of the cell wall (Sanchez et al., 2010). Surface proteins may interact with the host and mediate bacterial communication and chemical sensing in the environment, as well as immunomodulation of the host (Konstantinov et al., 2008; Le Maréchal et al., 2015). The functions of some surface proteins have been reviewed recently (Sánchez et al., 2010, 2013; GonzálezRodríguez et al., 2013).

Proteomics techniques can identify a large number of proteins in complex samples. Nevertheless, the identification of the bacterial surface proteome is a challenging task because of the difficulty of obtaining samples with almost no contamination of cytoplasmic proteins. Moreover, first-generation proteomics - separation of proteins by 2-dimensional electrophoresis and identification by matrix-assisted laser desorption/ionization time-of-flight mass spectrometry - cannot effectively detect bacterial surface proteins and membrane proteins because these proteins are normally hydrophobic and low abundance. Compared with gel-based approaches, gel-free second-generation proteomics have been successful in identifying microbial surface proteins, 
including the surface shaving method, which is shaving intact living cells by proteases (Insenser et al., 2010). After this approach was first applied to the pathogen Streptococcus pyogenes (Rodríguez-Ortega et al., 2006), it has become a common approach for a fast and reliable identification of surface proteins. This shaving strategy has already been applied to a wide variety of microorganisms, including gram-positive bacteria, such as Streptococcus pneumoniae (Olaya-Abril et al., 2013), Enterococcus faecalis V583 (Bøhle et al., 2011) and Lactococcus lactis (Meyrand et al., 2013b), and gram-negative bacteria, such as Listeria monocytogenes (Zhang et al., 2013), Escherichia coli (Walters and Mobley, 2009), and Salmonella enterica (Van Gerven et al., 2009). This method has also been used in eukaryotes, such as Saccharomyces cerevisiae (Braconi et al., 2011), Candida albicans (Vialás et al., 2012), and Schistosoma mansoni (Castro-Borges et al., 2011). Guglielmetti et al. (2008) identified the outer surface lipoprotein, BopA, of Bifidobacterium bifidum MIMBb75 by proteinase $\mathrm{K}$ and lithium chloride treatments, which plays a key role in bifidobacterial cell adhesion to Caco-2 cells (Guglielmetti et al., 2008). However, a systematic study of the surface-associated proteome of Bifidobacterium has not been carried out by shaving intact living bacterial cells.

Intracellular proteins may be released from cell lysis after trypsin treatment, and the surface-associated proteins identified would be contaminated by intracellular proteins (Bohle et al., 2011). Therefore, the assessment of bacterial cell viability and membrane integrity after trypsin treatment is vital for successful identification (Solis et al., 2010). The plate counting method is not a reliable method to evaluate bacterial cell viability and membrane integrity because some bacteria are viable and integral but not cultivable (Berney et al., 2008; Hammes et al., 2011). Quantitative real-time PCR (qPCR)combined with propidium monoazide (PMA) can accurately assess viability and integrity of bacterial cells compared with the plate counting method (Fujimoto et al., 2011; Villarreal et al., 2013).

Given the potential role of proteins located on the outer surface of Bifidobacterium in bifidobacterial adhesion to host, Bifidobacterium animalis ssp. lactis KLDS 2.0603, which adheres to Caco-2 intestinal epithelial cells, was chosen in the present study (Wang et al., 2013). Then, the surface proteins of this strain were systematically identified by surface shaving with trypsin and MS identification. The PMA-qPCR combined with electron microscopy was established as a method for observing bacterial cell viability and membrane integrity. The results will provide the basis for studies of the molecular mechanisms of interaction between Bifidobacterium and the host.

\section{MATERIALS AND METHODS}

\section{Bacterial Strains and Culture Conditions}

Bifidobacterium animalis ssp. lactis KLDS 2.0603 (KLDS, Key Lab of Dairy Science, Ministry of Education, Northeast Agricultural University, China), which was isolated from adult feces, was used in this study. The strain was cultured in modified de Man, Rogosa, and Sharpe broth containing $0.05 \%$ (wt/vol) cysteinehydrochloride at $37^{\circ} \mathrm{C}$ in an anaerobic chamber (Thermo Fisher Scientific, Nepean, ON, Canada) as previously described (Zhai et al., 2013).

\section{Surface Digestion of Live Cells}

Fifty milliliters of bacterial culture in midexponential growth phase (corresponding to approximately 108 cells) was removed and centrifuged at 5,000 $\times g$ for 10 min at $4^{\circ} \mathrm{C}$ and then washed 3 times with PBS. Cells were resuspended in $1.0 \mathrm{~mL}$ of PBS containing $30 \%$ sucrose. Shaving reactions were carried out with addition of $20 \mu \mathrm{g}$ of trypsin (Promega, Madison, WI) or no addition of trypsin (control samples). The samples were incubated for $2 \mathrm{~h}$ at $37^{\circ} \mathrm{C}$ with shaking at $150 \mathrm{rpm}$. The digestion mixtures were centrifuged at $3,500 \times g$ for 10 min at $4^{\circ} \mathrm{C}$, and the supernatants (containing proteins and the peptides) were filtered using $0.22-\mu \mathrm{m}$ filters (Millipore, Billerica, MA). An additional $2 \mu \mathrm{g}$ of trypsin was added to the supernatants, and the mixture was incubated for $24 \mathrm{~h}$ at $37^{\circ} \mathrm{C}$ with agitation at $150 \mathrm{rpm}$. The overnight trypsin digestion of the supernatants was stopped by adding formic acid to a final concentration of $0.1 \%$ ( $\mathrm{vol} / \mathrm{vol}$ ). Prior to nanoLC-MS/MS analysis, peptides were concentrated and purified using C18 Dynabeads (Invitrogen, Waltham, MA) as described by Rappsilber et al. (2003). Three independent biological replicates were carried out for each treatment.

\section{Determination of Cell Viability After Surface Digestion}

Total viable counts of $B$. animalis KLDS 2.0603 were determined by a pour plate method using de Man, Rogosa, and Sharpe agar after serial 10-fold dilution in maximum recovery diluent solution. Plates were incubated anaerobically at $37^{\circ} \mathrm{C}$ for $48 \mathrm{~h}$, and the colony-forming units were determined. Cell viability was expressed as the colony-forming units per milliliter before and after treatment with the enzyme $(1,2$, and $4 \mathrm{~h}$ ). Evaluation of bacterial viability by qPCR before and after enzyme treatment was performed as described by Desfossés-Foucault et al. (2012) with modification. This method consists of 4 steps, as follows. 
(1) PMA Treatment. Propidium monoazide (Biotium Inc., Hayward, CA) stock solution $(20 \mathrm{mM})$ was prepared by dissolving PMA in 20\% dimethyl sulfoxide and stored at $-20^{\circ} \mathrm{C}$ in the dark. Cell shaving samples were treated with $50 \mu \mathrm{M}$ PMA and were incubated at $20^{\circ} \mathrm{C}$ for $5 \mathrm{~min}$ in the dark. Then, the mixture was photoactivated for 2 min at a distance of approximately $20 \mathrm{~cm}$ from 500-W halogen light sources as described by Fujimoto et al. (2011). The PMA-treated bacterial cells were stored at $-20^{\circ} \mathrm{C}$ until DNA extraction was performed.

(2) DNA Extraction. Total genomic DNA from samples was obtained using a TIANamp Bacteria DNA Kit (Tiangen, Beijing, China) according to the manufacturer's instructions. The DNA samples were stored at $-20^{\circ} \mathrm{C}$.

(3) $q P C R$ Amplification. Primers for the B. animalis KLDS 2.0603 16S rRNA gene were designed for viable bacteria quantification (forward primer Bif-F: 5'-TCTGGCTCAGGATGAACGC-3'; reverse primer Bif-R: 5'-CACCGTTACACCGGGAATTC-3').

(4) Standard Curves. Serial dilutions (from $10^{9}-10^{4}$ $\mathrm{cfu} / \mathrm{mL}$ ) of bacterial cells were spiked and treated with PMA. The DNA was then extracted following the same protocol as the control samples (without treatment of trypsin). When the standard curves were made, the DNA from the highest bacterial concentration was serially diluted in nuclease-free water. The PCR amplifications were carried out in triplicate, and cycle threshold results were then plotted against the corresponding microbiological count (cfu/mL).

\section{SDS-PAGE Analysis}

To visualize proteins or protein fragments that were resistant to trypsin, $20 \mu \mathrm{L}$ of the supernatant obtained from the 24-h trypsinization was loaded on $10 \% \mathrm{Nu}-$ PAGE Novex Bis-Tris gels (Invitrogen) for SDS-PAGE analysis. The gels were stained using SilverSNAP Stain (Pierce, Rockford, IL) following the manufacturer's procedure.

\section{Observation of the Surface Characteristics of Bacterial Cells}

The bacterial cell morphology of $B$. animalis KLDS 2.0603 and the integrity of the bacterial cells were observed by scanning electron microscopy. Bacterial cell pellets were harvested by centrifugation $(5,000 \times g, 10$ min). The pellets were washed twice with cold PBS $(\mathrm{pH} 7.2)$ and then resuspended in shaving buffer. Bifidobacterium animalis KLDS 2.0603 was treated with trypsin and incubated for $1 \mathrm{~h}$ or $2 \mathrm{~h}$ at $37^{\circ} \mathrm{C}$. Bacterial cell suspensions were centrifuged at $5,000 \times g$ for 10 min and the supernatant was discarded. The cell pellets were resuspended in $\mathrm{NaCl}$ solution $(0.9 \%$, wt/vol) and fixed for $2 \mathrm{~h}$ in $2 \%$ (wt/vol) glutaraldehyde solution. The ultrastructure of the bacterial cells was examined with scanning electron microscopy. Cells not treated with trypsin were processed the same way (control).

Processing the samples for transmission electron microscopy was carried out as reported by Wang et al. (2013). After fixation, B. animalis KLDS 2.0603 cells were washed twice with PBS $(\mathrm{pH} 7.2)$. Control and treated cells were then spotted onto a vegetable parchment and adsorbed by the film with a copper screen. Bacterial cells of B. animalis KLDS 2.0603 adhering to the film were stained with $3 \%$ phosphotungstic acid and examined microscopically (magnification, $\times 40,000$ ).

\section{LC-Electrospray lonization MS/MS Analysis}

Experiments were performed on a Q Exactive mass spectrometer that was coupled to an EASY-nLC system (Thermo Fisher Scientific). Six microliters of each fraction was injected for nanoLC-MS/MS analysis. The peptide mixture $(5 \mu \mathrm{g})$ was loaded onto the C18-reversed phase column (Thermo Scientific Easy Column, $10 \mathrm{~cm}$ long, $75 \mu \mathrm{m}$ inner diameter, $3 \mu \mathrm{m}$ resin) in buffer A ( $0.1 \%$ formic acid) and separated with a linear gradient of buffer B ( $80 \%$ acetonitrile and $0.1 \%$ formic acid) at a flow rate of $250 \mathrm{~nL} / \mathrm{min}$ controlled by IntelliFlow technology (Thermo Fisher Scientific, Waltham, MA) for 140 min. Mass spectometry data were acquired using a data-dependent top 10 precursor ions method, dynamically choosing the most abundant precursor ions from the survey scan $(300-1,800 \mathrm{~m} / z)$ for highenergy collision-induced dissociation fragmentation. Determination of the target value is based on predictive automatic gain control. The dynamic exclusion duration was $60 \mathrm{~s}$. Survey scans were acquired at a resolution of 70,000 at $m / z 200$, and the resolution was set to 17,500 at $m / z 200$ for high-energy collision-induced dissociation spectra. The normalized collision energy was $30 \mathrm{eV}$, and the underfill ratio, which specifies the minimum percentage of the target value likely to be reached at maximum-fill time, was defined as $0.1 \%$.

\section{Sequence Database Searching and Data Analysis}

The MS/MS spectra were searched using the MASCOT engine (version 2.2; Matrix Science, London, UK) against the UniProt Bifidobacterium database (released January 2014; 117795 sequences, http://www.uniprot. org/). The parameters used for protein identification were as follows: peptide mass tolerance at $20 \mathrm{ppm}, \mathrm{MS}$ / 
MS tolerance at $0.1 \mathrm{Da}$, trypsin with the number of missed cleavage up to 2, fixed modification: carbamidomethyl $(\mathrm{C})$, variable modification:oxidation $(\mathrm{M})$.

\section{Bioinformatic Analysis of the Identified Proteins}

Subcellular localization predictions of all proteins identified were carried out as described (Olaya-Abril et al., 2012; Cao and Bazemore-Walker, 2014). Briefly, we used the web-based PSORTb v.3.0 software (http:// www.psort.org/psortb/) to predict subcellular localization of identified proteins. Other software programs were also used to analyze sequence features of these proteins: TMHMM-2.0 (Krogh et al., 2001) for searching transmembrane helices; SignalP 4.0 (Bendtsen et al., 2004b) for identifying type-I signal peptides; and LipoP (Juncker et al., 2003) for identifying type-II signal peptides, which lipoproteins possess. Prediction of nonclassically secreted proteins was performed using the SecretomeP 2.0 Server (Bendtsen et al., 2004a). Subcellular locations of identified proteins were compared with those of the KLDS 2.0603 genome. The whole genome sequencing and annotating of B. animalis KLDS 2.0603 has been performed previously in our laboratory and deposited in the NCBI database (accession number CP007522.1). Protein sequence alignments of the proteins identified by MS were carried out using BLASTP from the National Center for Biotechnology Information (http://blast.ncbi.nlm.nih.gov/Blast.cgi) against the nonredundant protein sequences (nr) database. All identified proteins were classified based on gene ontology (GO) categories using the Web Gene Ontology Annotation Plot (WEGO; Ye et al., 2006). All identified proteins were further categorized into 3 functional groups: molecular function, cellular components, and biological processes (http://wego.genomics. org.cn/cgi-bin/wego/index.pl).

\section{RESULTS}

\section{Survival of B. animalis KLDS 2.0603 Before and After Trypsin Treatment}

Viability of $B$. animalis KLDS 2.0603 cells was evaluated before and after trypsin treatment $(1,2$, and 4 h) using 3 methodologies (plate counting, qPCR, and PMA-qPCR; Table 1). Viability of the bacterial cells was influenced by the method employed and time of trypsin treatment. Higher cell counts were always obtained by the qPCR method compared with the results from the plate counting and the PMA-qPCR techniques because the qPCR method was unable to distinguish live cells from dead cells. Likewise, results obtained by plate counting were lower than those obtained by the other 2 methods after $2 \mathrm{~h}$ of trypsin treatment. Viable bifidobacterial counts dropped significantly after $4 \mathrm{~h}$ of trypsin treatment using the PMA-qPCR method (from 6.43 to $\left.1.01 \times 10^{9} \mathrm{cfu} / \mathrm{mL}\right)$ and the plate counting method (from 4.89 to $0.37 \times 10^{9} \mathrm{cfu} / \mathrm{mL}$ ). Therefore, 2 $\mathrm{h}$ of trypsin treatment was chosen for surface digestion of live cells.

\section{Surface Examination of Bifidobacterial Cells Subjected to Trypsin Shaving}

Scanning electron microscopy was used to observe the morphology of bacterial cells subjected to trypsin shaving, and transmission electron microscopy was used to assess the integrity of the cytoplasmic membrane. When the cells were subjected to trypsin treatment (1 and $2 \mathrm{~h}$ ), bacterial cells still maintained an intact morphology (Figure 1E and F), and the cytoplasmic membrane was clearly observed and integral (Figure 1B and $\mathrm{C}$ ), which suggested that bacterial cells were not lysed after enzymatic shaving even after $2 \mathrm{~h}$ of treatment, likely because of the strong cell wall (Figure 1C and F).

\section{Identification of Outer Surface-Associated Proteins}

The extracted surface-associated proteins were analyzed by SDS-PAGE (Figure 2). Similarities between different samples treated by trypsin were high according to the protein bands, as shown in Figure 2. A total of 105 surface-associated proteins were identified (Table 2 ). The subcellular locations of the identified proteins were predicted by PSORT, SignalP 4.0, LipoP, SecretomeP 2.0, and TMHMM-2.0 and are shown in Table 3 compared with results of the genome of $B$. animalis ssp. lactis KLDS 2.0603. Most identified proteins did not possess traditional secretion signals or recognizable anchoring motifs. Sixteen proteins had a signal peptide sequence, as shown in Table 4, and 15 proteins out of 105 were potentially related to adhesion and interaction between the bacteria and host, based on genome analysis and previous experimental evidence (references in Table 2).

\section{Biological Functional Analysis of Cell Surface Proteins}

Gene ontology annotation of 76 proteins from the 105 surface-associated proteins was available. Based on the GO hierarchy obtained by WEGO, proteins were classified into cellular components, molecular functions, and biological processes (Figure 3). The cellular components ontology of proteins refers to the location in the cell where proteins are active (Ashburner et al., 2000). Of 
Table 1. Survival of Bifidobacterium animalis ssp. lactis KLDS 2.0603 after trypsin digestion of 1 or $2 \mathrm{~h}( \pm$ $\mathrm{SD})$

\begin{tabular}{lccc}
\hline & \multicolumn{3}{c}{ Method of analysis $\left(\times 10^{9} \mathrm{cfu} / \mathrm{mL}\right)$} \\
\cline { 2 - 4 } Digestion time & $\begin{array}{c}\text { Plate } \\
\text { counting }\end{array}$ & $\begin{array}{c}\text { Quantitative real-time } \\
\text { PCR }(\mathrm{qPCR})\end{array}$ & $\begin{array}{c}\text { qPCR with propidium } \\
\text { monoazide }\end{array}$ \\
\hline $0 \mathrm{~h}($ control) & $8.70 \pm 1.20$ & $9.84 \pm 0.80$ & $9.10 \pm 0.65$ \\
$1 \mathrm{~h}$ & $7.03 \pm 0.78$ & $8.29 \pm 0.36$ & $8.01 \pm 0.46$ \\
$2 \mathrm{~h}$ & $4.89 \pm 0.34$ & $7.20 \pm 0.43$ & $6.43 \pm 0.42$ \\
$4 \mathrm{~h}$ & $0.37 \pm 0.13$ & $2.96 \pm 1.28$ & $1.01 \pm 0.78$ \\
\hline
\end{tabular}

these proteins, 46 were in the cell (GO:0005623) and 21 were on the ribosome (GO:0015935, GO:0005840), with the remainder located in the membrane (GO:001602), extracellular region (GO:0005576), and macromolecular complexes (GO:0043234, GO:0000015).

We used 8 subcategories for the molecular function ontology, but binding activity, catalytic activity, structural molecules, and transporters are the 4 main molecular function categories. Most of the assigned binding activity was protein binding, RNA binding, and nucleotide binding, and most proteins had catalytic activity, which is related to carbohydrate metabolism (e.g., acetate kinase, enolase, and transaldolase). Six proteins contained ABC transporter domains for metabolism and transport of sugars and AA.

In the biological process category, a large proportion of proteins was related to cellular and metabolic processes. Most of the cellular and metabolic processes were related to carbohydrate, nucleotide, and AA metabolism, which may play an important role in nutrition for bifidobacteria during adaptation to the intestinal tract environment.

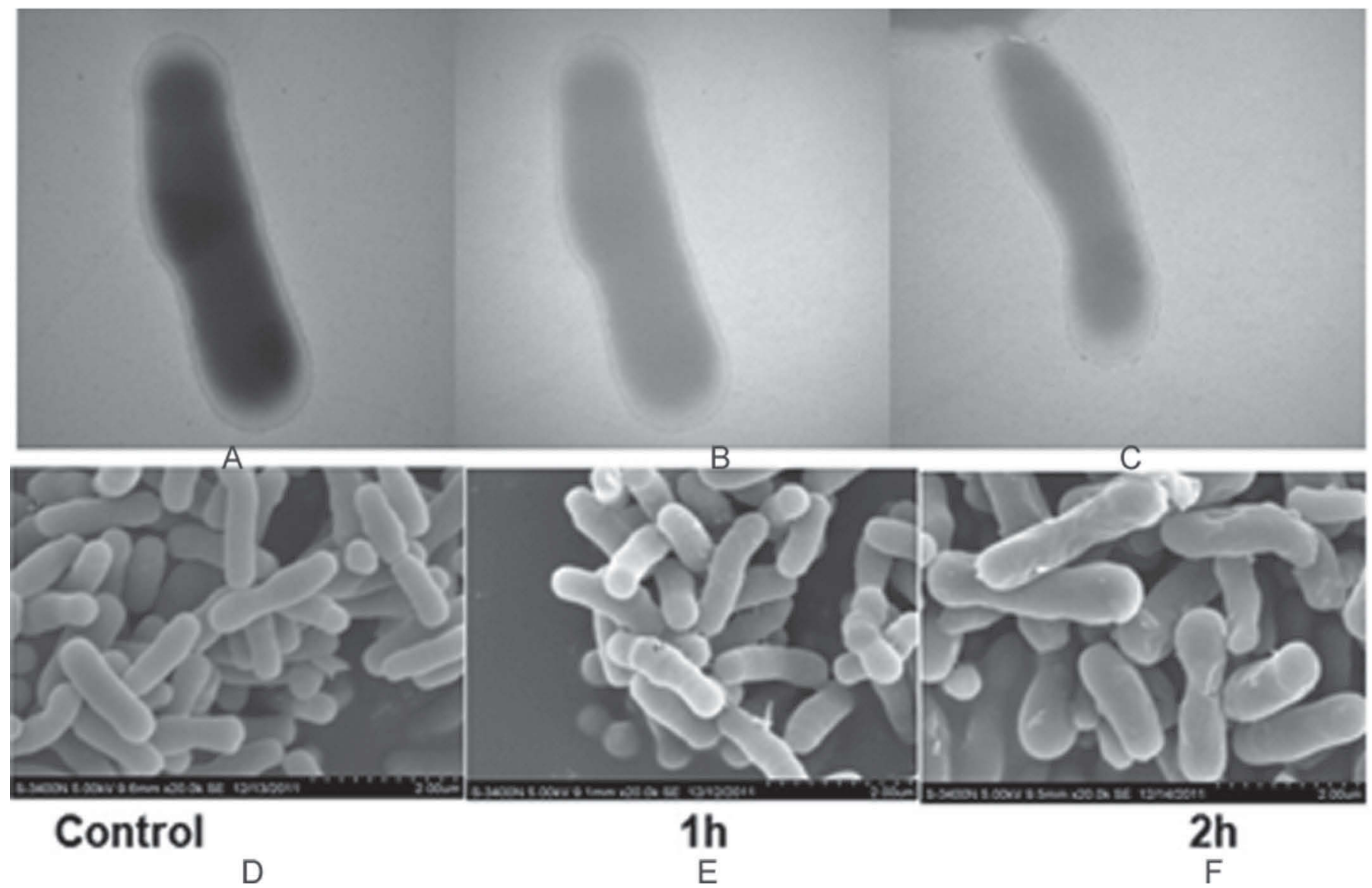

Figure 1. Transmission (A, B, C) and scanning (D, E, F) electron microscopy micrographs of Bifidobacterium animalis ssp. lactis KLDS 2.0603 at 0 (A, D; control), 1 (B, E), and $2 \mathrm{~h}(\mathrm{C}, \mathrm{F})$ of treatment with $20 \mu \mathrm{g}$ of trypsin. 


\section{DISCUSSION}

\section{Optimization of Bacterial Treatment for Surface Shaving Identification}

Before surface shaving was carried out, the effect of the trypsin treatment on the integrity of bifidobacterial cells was assessed. We assessed the effect of incubation time (30 min to $4 \mathrm{~h}$ ) on bacterial viability and bacterial integrity in hypertonic buffer, which consists of PBS $/ 30 \%$ sucrose $\mathrm{pH} 7.4$ containing $20 \mu \mathrm{g}$ of trypsin in 50-mL cultures, using 3 methods (plate counting, qPCR, and PMA-qPCR). According to previous reports, $4 \mathrm{~h}$ of treatment was the longest time used (Severin et al., 2007), and $2 \mathrm{~h}$ of treatment was commonly used (Bohle et al., 2011). Although an incubation time of $2 \mathrm{~h}$ led to a significant reduction in the counts obtained by plate counting, the cell membrane and morphology of most cells were intact according to the PMA-qPCR results (Table 1) and transmission electron microscopy and scanning electron microscopy (Figure 1). The qPCR method is unable to distinguish between live and dead cells (Fujimoto et al., 2011; Villarreal et al., 2013); however, PMA-qPCR enables the amplification of DNA from viable but not dead bacterial cells (Fujimoto et al., 2011; Villarreal et al., 2013). Compared with the plate counting method, PMA-qPCR accurately assesses integrity of bacterial cells, especially for bacteria that are viable and integral but not culturable (Villarreal et al., 2013). The long incubation time $(4 \mathrm{~h})$ led to an obvious decrease in viability and would likely result in an increase in the fraction of cytoplasmic proteins. However, the lysis of bacterial cells after the enzymatic treatment for $2 \mathrm{~h}$ was low. Therefore, $2 \mathrm{~h}$ was chosen for surface shaving identification. This shaving method was also used in another study (Benachour et al., 2009).

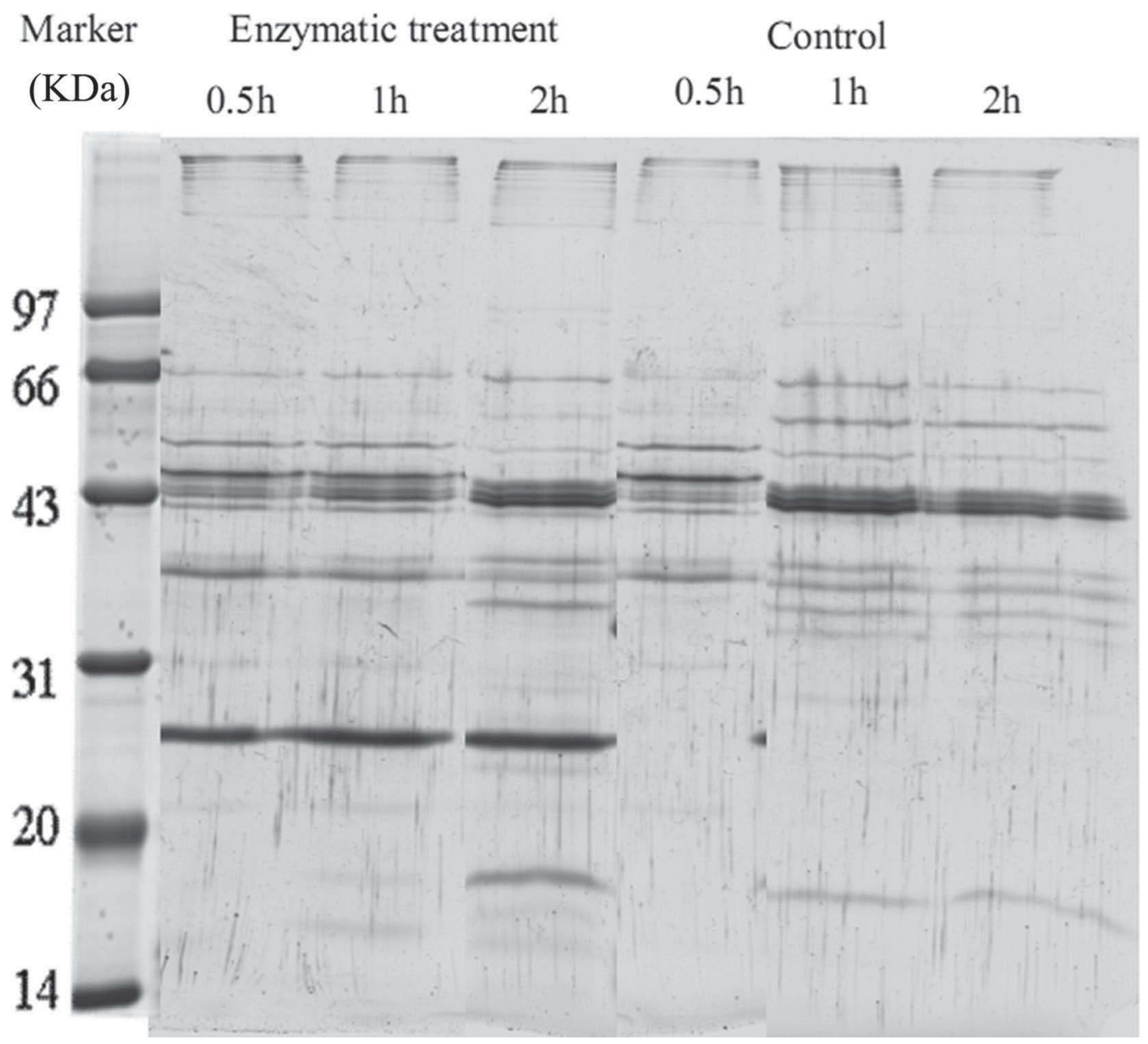

Figure 2. Sodium dodecyl sulfate-PAGE analysis of the supernatants obtained from intact cells treated with $20 \mu \mathrm{g}$ of trypsin for $0.5,1$, and $2 \mathrm{~h}$. The group with no enzymatic treatment was included as a control. 


\section{Bioinformatics Analysis of Surface- Associated Proteins}

The subcellular localization of all 105 identified proteins was analyzed using a variety of bioinformatic tools (PSORTb, SignalP 4.0, LipoP1.0, SecretomeP 2.0, and TMHMM). The results are shown in Table 2 and are discussed in each section.

\section{Signal Peptide-Containing Proteins}

Bacterial signal peptides include 4 major classes: secretary signal peptides (cleaved by signal peptidase I, SPase I), twin-arginine signal peptides (cleaved by SPase I), possible lipoprotein precursors (cleaved by signal peptidase II, SPase II), and type IV pilin signal peptides. Overall, we identified 16 proteins with a signal peptide, which accounted for $16 \%$ of all proteins identified (Table 4). These results showed that most proteins did not have conventional export pathways. Twelve of 16 proteins had secretary signal peptides cleaved by SPase I, whereas the other 4 proteins (solute-binding protein of the $\mathrm{ABC}$ transporter for peptides, $\mathrm{ABC}$ transporter substrate-binding protein, $\mathrm{ABC}$ transporter solute-binding protein, and dipeptide-binding $\mathrm{ABC}$ transporter periplasmic substrate-binding component) had signal peptidase SPase II cleavage sites. However, one protein of these proteins, FimB (fimbrial subunit), contained a C-terminal LPXTG motif, which was cell wall anchored (Table 4).

\section{Cytoplasmic Proteins}

Eighty-nine proteins out of the 105 identified proteins lack signal peptide sequences according to the prediction by PSORTb v.3.0. Fifty proteins out of 89 proteins were predicted to be cytoplasmic proteins, and 14 proteins did not possess exact subcellular locations because they lacked obvious sequence features. All these proteins were predicted to be nonclassical secretion proteins by SecretomeP, and the results also suggested that these proteins were not secreted by nonclassical secretion pathways.

Identification of cytoplasmic proteins on the bacterial surface and extracellular locations is common. For example, at least 20 cytoplasmic proteins were found in the surface proteome of Enterococcus faecalis (Benachour et al., 2009). In our study, many of the cytoplasmic proteins identified were highly abundant, including ribosomal proteins (Rbp), elongation factors (EF-T), enolase, transaldolase, GADPH, bile salt hydrolase and chaperones (GroES, GroEL, DnaK, and others; Table 2). The occurrence of cytoplasmic proteins on the surface of the cells may be due to 3 reasons. First, these cytoplasmic proteins may come from cell lysis. Although we tried to control cell lysis when surface shaving was carried out, cell lysis still exists to some extent. Some strategies, including harvesting cell samples from logarithmic cultures, have been used to maximize the number of identifiable surface proteins without contamination of cytoplasmic proteins, and shaving experiments were also conducted under hypertonic conditions with sucrose, which decreases the release of cytoplasmic proteins (Espino et al., 2015). We also determined the bacterial cell viability and integrity using both PMAqPCR and electron microscopy, and the results indicated that $2 \mathrm{~h}$ of trypsin treatment did not result in much bacterial cell lysis. Moreover, intracellular proteins were released due to cell lysis during culturing before trypsin treatment. Second, some cytoplasmic proteins are present at the cell surface, but their secretion pathways are unknown. For example some cytoplasmic proteins possess extracellular functions. Thus, these proteins are called moonlighting proteins. Some extracellular moonlighting proteins (EF-Tu, DnaK, enolase, and GAPDH) have adhesive roles. Third, when these proteins are trapped in membrane-bound vesicle structures, they can be released to the surface by shedding (Olaya-Abril et al., 2014).

\section{Extracellular Proteins}

The proteins that contain sequences with SPaseI cleavage sites but did not have cell wall-binding domains were classified as extracellular proteins. Eight extracellular proteins were identified and accounted for $53.3 \%$ of extracellular proteins in the $B$. animalis KLDS 2.0603 genome (Table 3), which was high compared with a previous study (Bohle et al., 2011). Among 8 extracellular proteins, 3 proteins were uncharacterized proteins whose functions were unknown. Two surface antigen proteins (NLP/P60 family protein, immunogenic secreted protein) were involved in triggering the immune response (Lei et al., 2000; Yan et al., 2007a). One protein (cell wall-associated hydrolase) was related to biogenesis of the cell wall and membrane (Sánchez et al., 2008). The other 2 proteins (one sugar-binding secreted protein and one fibro-slime domain protein) have similar functions.

\section{Proteins on the Surface}

Proteins on the bacterial surface theoretically consist of cell wall- and cell membrane-anchored proteins. Among the 105 proteins, 4 proteins contain the LPXTG cell wall-anchored motif, and 23 were nonsecreted and 


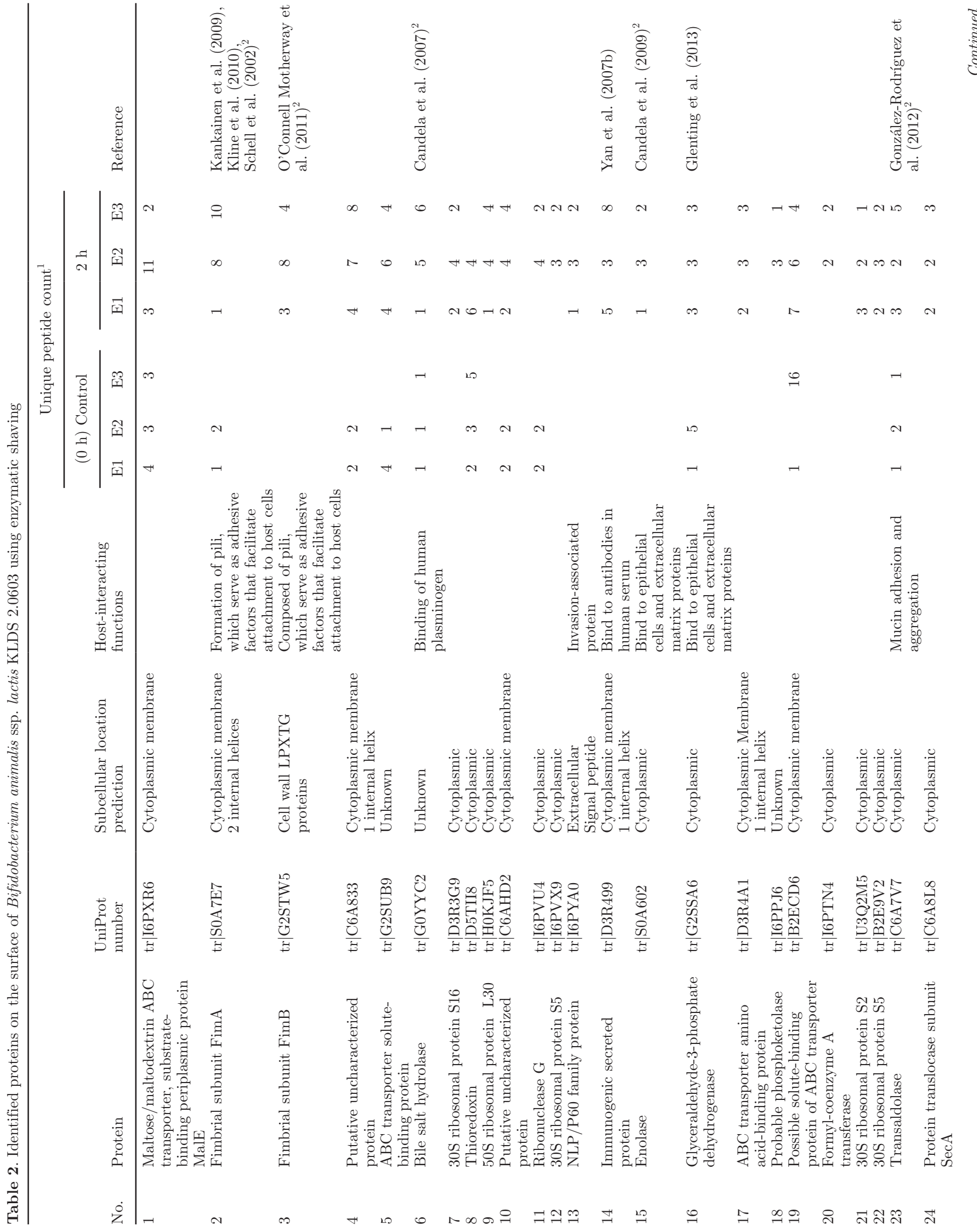




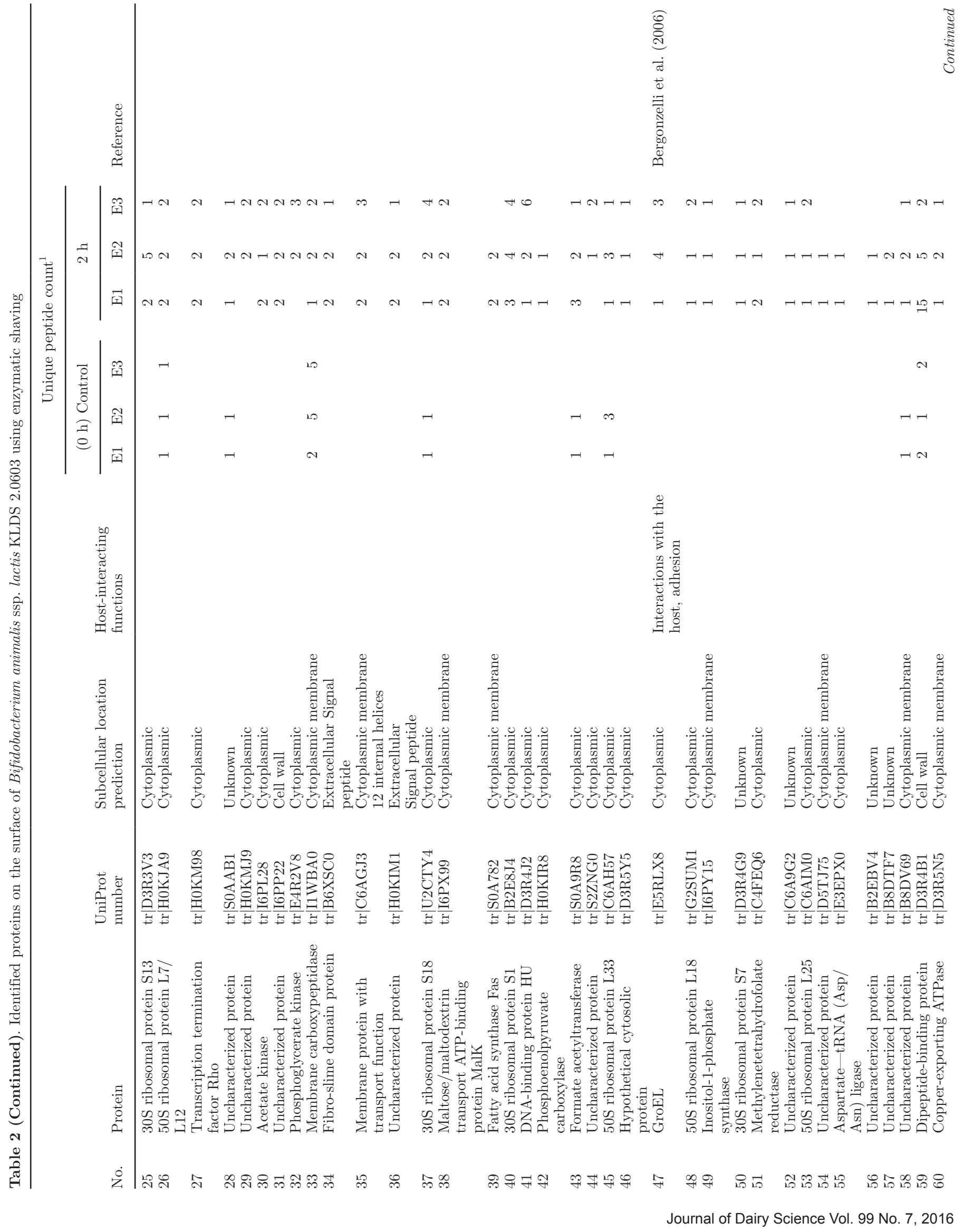




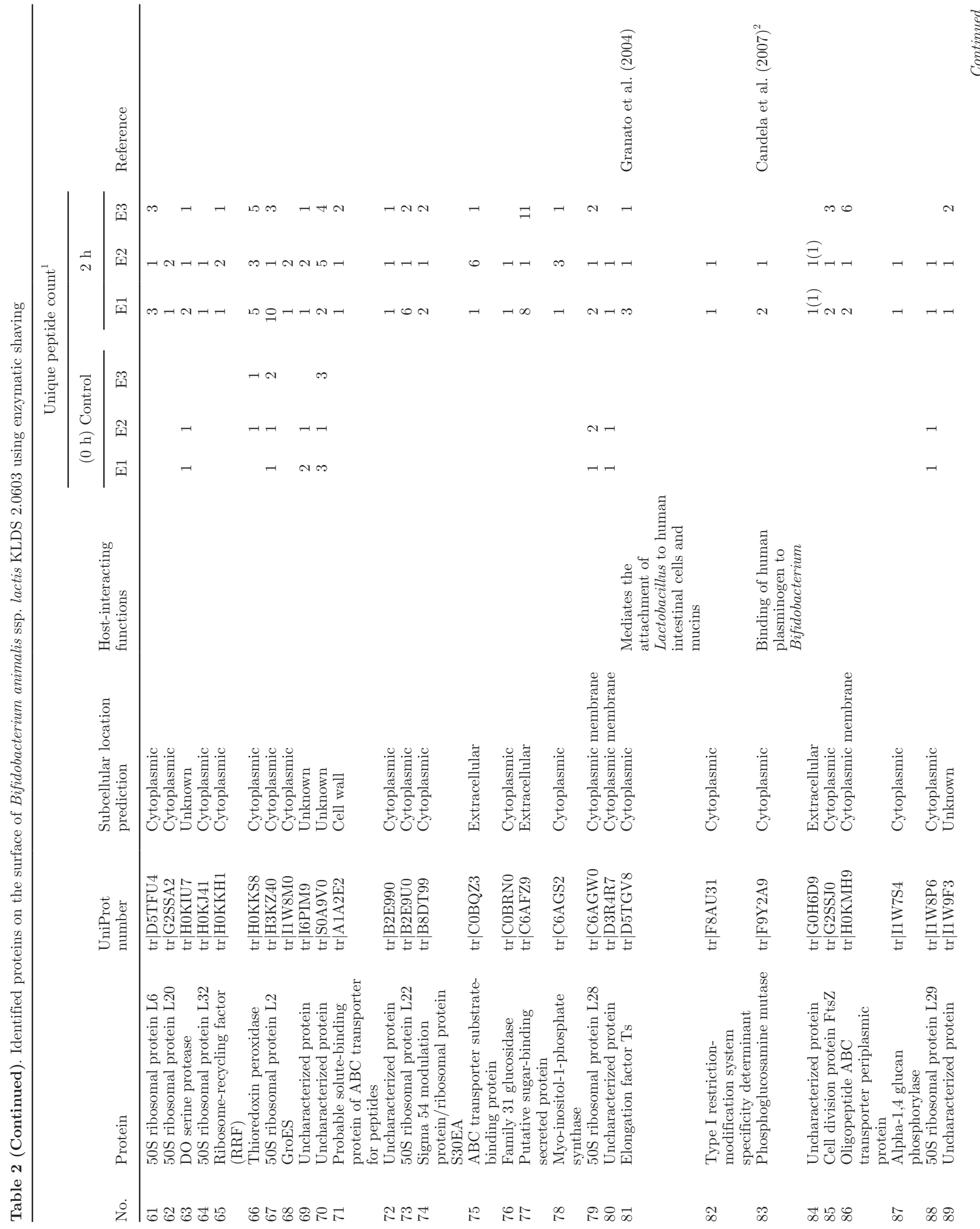




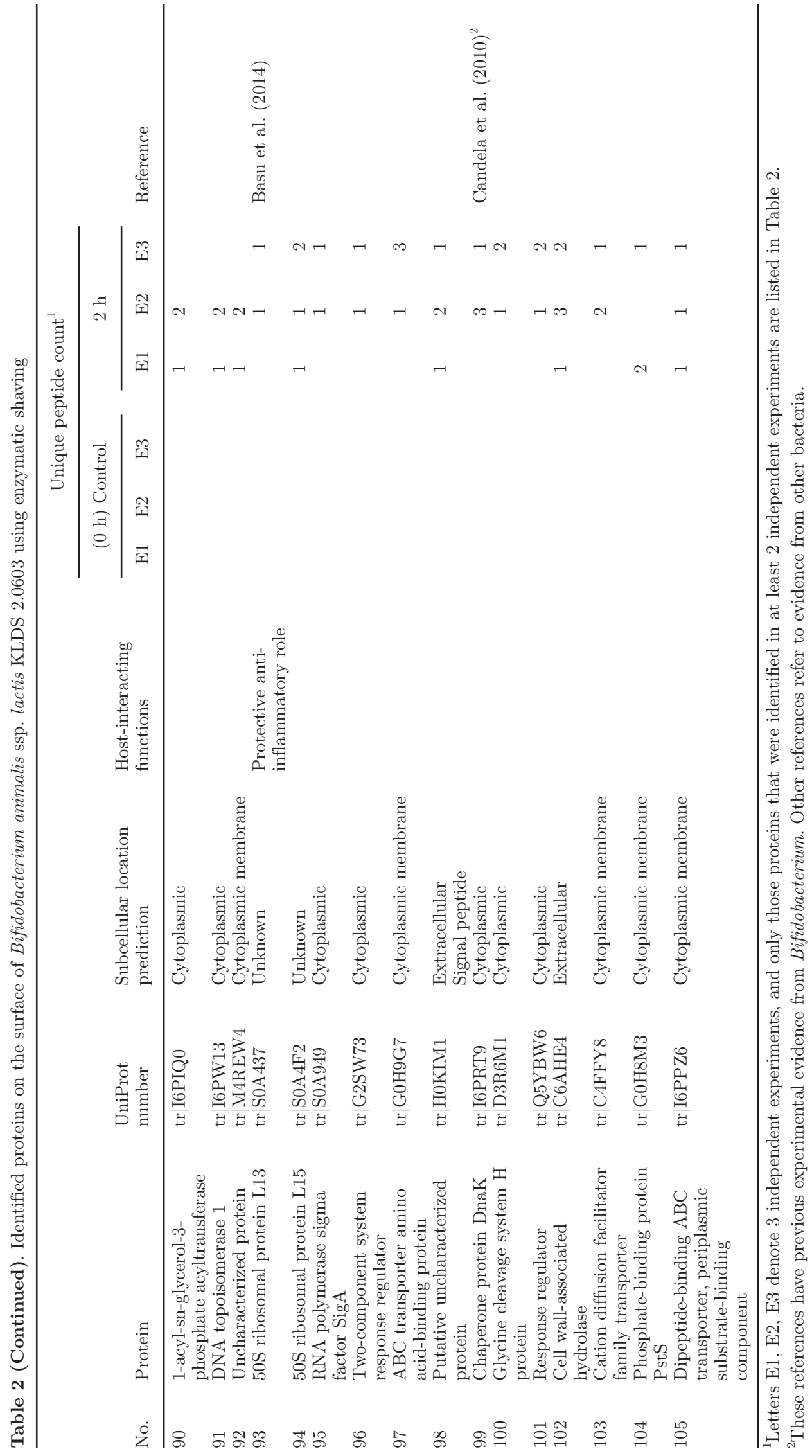


Table 3. Summary of subcellular locations of the identified proteins and genome of Bifidobacterium animalis ssp. lactis KLDS 2.0603 predicted by PSORT, SignalP 4.0, LipoP, SecretomeP 2.0, and TMHMM-2.0 (CBS Prediction Servers, http://www.cbs.dtu.dk/services/)

\begin{tabular}{lccc}
\hline Predicted localization & $\begin{array}{c}\text { Number of identified } \\
\text { proteins }\end{array}$ & $\begin{array}{c}\text { Number in the B. animalis } \\
\text { KLDS 2.0603 genome }\end{array}$ & $\begin{array}{c}\text { Identified } \\
(\%)\end{array}$ \\
\hline Cytoplasmic & 56 & 922 & 6.07 \\
Cytoplasmic membrane & 23 & 448 & 5.13 \\
Extracellular & 8 & 15 & 53.3 \\
Cell wall associated & 4 & 7 & 57.1 \\
Signal peptide-containing & 16 & 57 & 28.1 \\
Lipoprotein & 19 & 56 & 33.9 \\
LPXTG & 1 & 289 & 5.8 \\
Unknown & 14 & 4.8 \\
\hline
\end{tabular}

noncytoplasmic proteins (Table 3) that were classified as integral membrane proteins. Among 4 cell wall proteins, 3 proteins had functional annotations and 1 protein was uncharacterized. Among 3 proteins with functional annotations, 1 protein was involved in pilus biogenesis (fimbrial subunit FimB), which has usually been detected in bacterial surface proteome analyses (Meyrand et al., 2013a; Espino et al., 2015), and the other 2 proteins were related to solute binding (Gilad et al., 2011). We identified only $0.5 \%$ of the predicted transmembrane proteins in the $B$. animalis KLDS 2.0603 genome (Table 3). Such a low percentage of identified transmembrane proteins is common and similar to the results obtained in another study (Bohle et al., 2011). This is due to 2 reasons: first, expression of these proteins is kept to low levels, and second, the treatment with trypsin is unlikely to penetrate the thick cell wall. Therefore, these proteins could not be identified. More peptides matched the 3 identified transmembrane proteins (MalE, FimA, FimB) than those matching the other 23 transmembrane proteins (see Table 2).

The 19 transmembrane proteins are lipoproteins, representing $31 \%$ of the lipoproteins putatively encoded by the B. animalis KLDS 2.0603 genome (Table 3); six lipoproteins possess similar functions. Of 10 lipoproteins with predicted functions, 6 are related to the $\mathrm{ABC}$ transporter system involved in AA or carbohydrate transport and metabolism. Five transmembrane proteins are uncharacterized proteins according to predictions. Two proteins (FimA, FimB) are involved in pilus assembly, which is important in adhesion and host colonization (Danne and Dramsi, 2012). FimB contain a putative LPXTG anchor motif, which has adhesive functions (Danne and Dramsi, 2012).

\section{Proteins Related to Adhesion and Host Interactions}

Adhesion of bifidobacteria to human intestinal cells or extracellular matrix proteins is a vital step for in- testinal colonization. Bifidobacterium have been shown not only to adhere to a variety of epithelial cells in vitro but also to inhibit adhesion of pathogenic enterobacteria. Some components of bifidobacteria act as adhesive factors, including lipoteichoic acids (Op den Camp et al., 1985), carbohydrates (Fanning et al., 2012a,b), extracellular proteins (González-Rodríguez et al., 2012), and surface proteins located on the outer surface of the cell wall. Bifidobacterial surface proteins play an important role in adhesion and colonization, as they directly interact with mucosal cells, such as epithelial and immune cells (Lebeer et al., 2010). However, until now, a comprehensive study of the outer surface-associated proteome of bifidobacteria has not been carried out.

The global profile of the bifidobacterial surface proteome was available by shaving living cells with enzyme in this study. A total of 105 surface-associated proteins were found, and 15 proteins were potentially related to adhesion and interactions between the bacteria and host according to previous experimental evidence (Table 2, Figure 4.). The proteins related to adhesion and interactions between bacteria and host include pilus proteins (Fim A, Fim B), 10 moonlighting proteins, a NLP/P60 family protein, an immunogenic secreted protein, and a putative sugar-binding secreted protein (Table 2, Figure 4.). The potential functions include binding of plasminogen, formation of pili, adhesion to collagen, adhesion to mucin and intestinal cells, a protective anti-inflammatory role, and stimulation of immune reactions (Table 2).

Bacterial pili can serve as adhesive factors, which mediate interaction with host cells (Mandlik et al., 2008; Danne and Dramsi, 2012). Pili are composed of 2 pilus subunits (Fim A, Fim B), which contain a sortase recognition motif, sortase, and a hypothetical protein (Gilad et al., 2011). The adhesive role of pili were revealed in Lactobacillus rhamnosus GG (Kankainen et al., 2009) and Bifidobacterium breve by immunogold electron micrograph. Those 2 studies showed that binding to mu- 
IDENTIFICATION OF SURFACE-ASSOCIATED PROTEINS

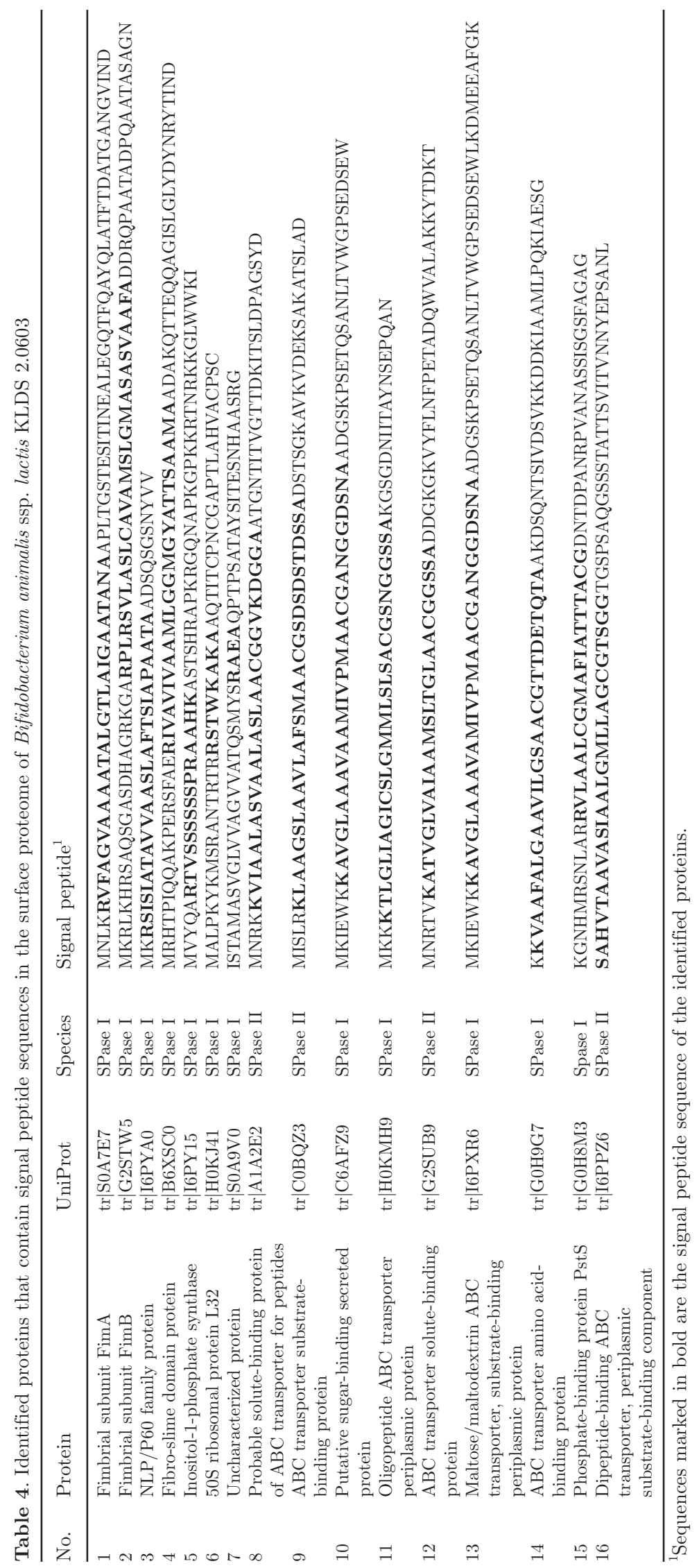

Journal of Dairy Science Vol. 99 No. 7, 2016 


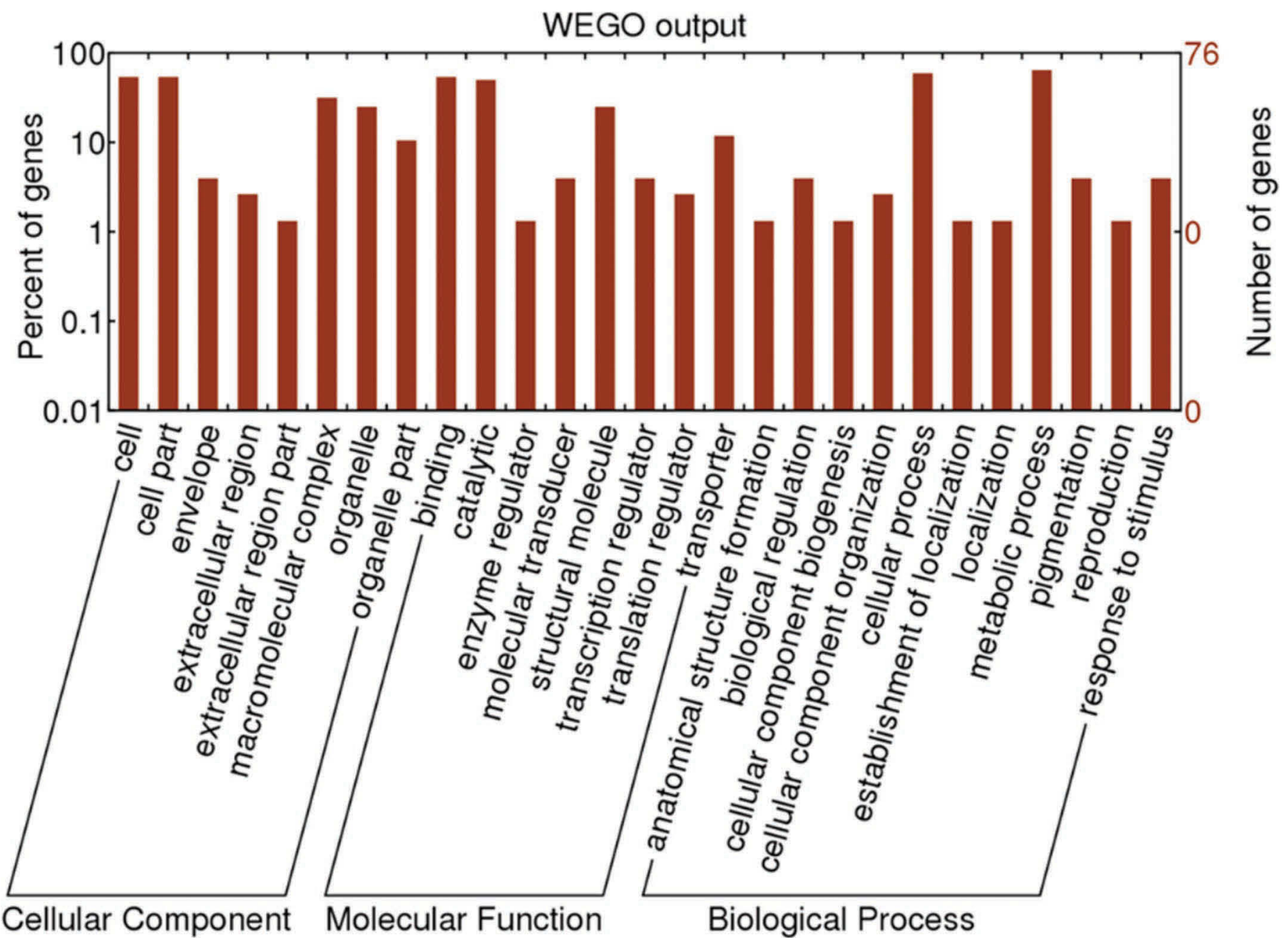

Figure 3. Gene ontology (GO) categories of surface-associated proteins of Bifidobacterium animalis ssp. lactis KLDS 2.0603. The identified proteins were classified into cellular components, molecular functions, and biological processes by the Web Gene Ontology Annotation Plot (WEGO) according to their GO characteristics. Color version available online.

cus depended strongly on the expression of one of the pilus subunits. Some bifidobacterial genome sequences harbor clusters of genes encoding pili (Kankainen et al., 2009; Foroni et al., 2011; O'Connell Motherway et al., 2011). In the present study, 2 pilus subunit proteins (FimA and Fim B) were identified from bifidobacterial surface by gel-free shotgun proteomics (Table 2, Figure 4).

A second group of adhesive proteins were moonlighting proteins, which apparently lack secretion signals or binding domains. However, these moonlighting proteins have adhesive functions when on the bacterial surface in addition to their primary role in bacterial metabolism in cytoplasm. This group of proteins usually includes glycolytic and other related enzymes (enolase, transaldolase, bile salt hydrolase, phosphoglucosamine mutase, GAPDH), housekeeping proteins (EF-T), molecular chaperones (GroEL, GroES, DnaK), and ribosomal proteins (50S ribosomal protein L13). Once these moonlighting proteins are exposed to the bacterial surface, they will develop adhesive functions. For this reason, they are described as moonlighting proteins.

\section{CONCLUSIONS}

Bifidobacteria usually exert their beneficial effects through adhesion or direct interaction with host cells (mainly enterocytes and immune cells) via surface-associated proteins or other factors, triggering downstream responses. The global profile of bifidobacterial surfaceassociated proteins was obtained by the shaving approach, which has already been shown to be a fast and 
reliable way to identify surface-associated proteins. A total of 105 surface-associated proteins were found, and 15 proteins could potentially be involved in adhesion and interactions between bacteria and the host in the intestinal tract. The proteins related to adhesion and interactions include pilus structure proteins (Fim A,
Fim B), 10 moonlighting proteins, an NLP/P60 family protein, an immunogenic secreted protein, and a putative sugar-binding secreted protein. Further research will be needed to determine their exact function, especially for proteins with unknown functions that may potentially be involved in the adhesion of bifidobacteria

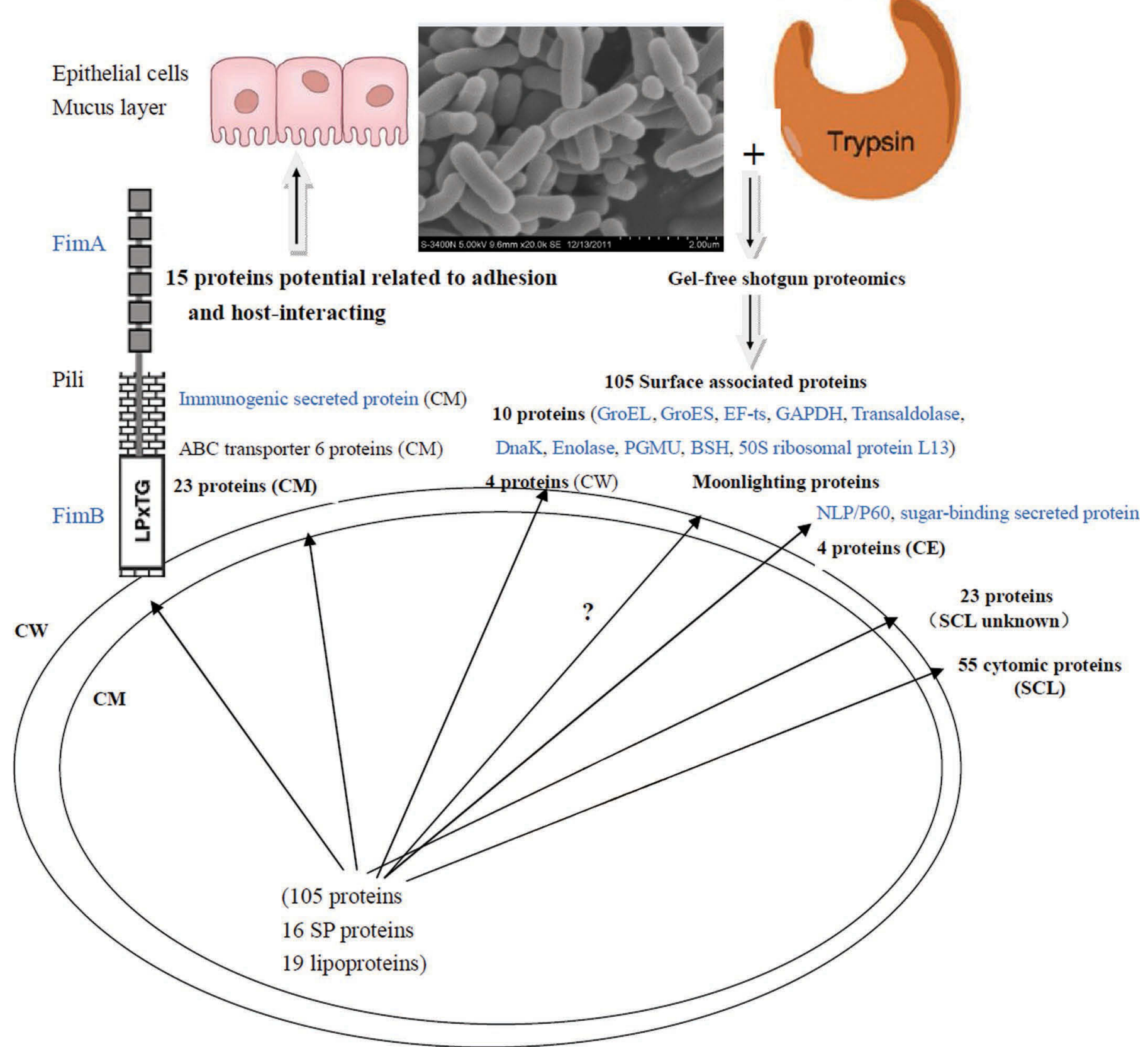

Figure 4. Overview of surface-associated proteins of Bifidobacterium animalis ssp. lactis KLDS 2.0603, which illustrates classification of subcellular locations (SCL) of these proteins and summarizes proteins related to adhesion and interaction with host. CM $=$ cell membrane; CW $=$ cell wall; $\mathrm{CE}=$ extracellular; PGMU = phosphoglucosamine mutase; BSH = bile salt hydrolase; SP proteins = proteins containing signal peptide. Proteins marked in gray (blue) are potentially involved in interactions between bifidobacteria and the host. Color version available online. 
to the intestinal cells. These results provide the basis for future studies on relevant adhesive biomarkers and detailed analyses of the mechanisms of probiotics.

\section{ACKNOWLEDGMENTS}

This work was supported by the National Natural Science Foundation of China (China; No. 31171719), the key technology research projects of the Ministry of Education (China; 213012A) and the Outstanding Youth Scientists Foundation of Harbin City (China; 2014RFYXJ006).

\section{REFERENCES}

Albers, S. V., and A. M. Driessen. 2002. Signal peptides of secreted proteins of the archaeon Sulfolobus solfataricus: A genomic survey. Arch. Microbiol. 177:209-216.

Ashburner, M., C. A. Ball, J. A. Blake, D. Botstein, H. Butler, J. M. Cherry, A. P. Davis, K. Dolinski, S. S. Dwight, J. T. Eppig, M. A. Harris, D. P. Hill, L. Issel-Tarver, A. Kasarskis, S. Lewis, J. C. Matese, J. E. Richardson, M. Ringwald, G. M. Rubin, and G. Sherlock. 2000. Gene ontology: Tool for the unification of biology. The Gene Ontology Consortium. Nat. Genet. 25:25-29.

Basu, A., D. Poddar, P. Robinet, J. D. Smith, M. Febbraio, W. M. Baldwin 3rd, and B. Mazumder. 2014. Ribosomal protein L13a deficiency in macrophages promotes atherosclerosis by limiting translation control-dependent retardation of inflammation. Arterioscler. Thromb. Vasc. Biol. 34:533-542.

Benachour, A., T. Morin, L. Hebert, A. Budin-Verneuil, A. Le Jeune, Y. Auffray, and V. Pichereau. 2009. Identification of secreted and surface proteins from Enterococcus faecalis. Can. J. Microbiol. 55:967-974.

Bendtsen, J. D., L. J. Jensen, N. Blom, G. Von Heijne, and S. Brunak. 2004a. Feature-based prediction of non-classical and leaderless protein secretion. Protein engineering, design \& selection. Protein Eng. Des. Sel. 17:349-356.

Bendtsen, J. D., H. Nielsen, G. von Heijne, and S. Brunak. 2004b. Improved prediction of signal peptides: SignalP 3.0. J. Mol. Biol. 340:783-795.

Bergonzelli, G. E., D. Granato, R. D. Pridmore, L. F. Marvin-Guy, D. Donnicola, and I. E. Corthesy-Theulaz. 2006. GroEL of Lactobacillus johnsonii La1 (NCC 533) is cell surface associated: Potential role in interactions with the host and the gastric pathogen Helicobacter pylori. Infect. Immun. 74:425-434.

Berney, M., M. Vital, I. Hülshoff, H.-U. Weilenmann, T. Egli, and F. Hammes. 2008. Rapid, cultivation-independent assessment of microbial viability in drinking water. Water Res. 42:4010-4018.

Bøhle, L. A., T. Riaz, W. Egge-Jacobsen, M. Skaugen, O. L. Busk, V. G. Eijsink, and G. Mathiesen. 2011. Identification of surface proteins in Enterococcus faecalis V583. BMC Genomics 12:135.

Braconi, D., L. Amato, G. Bernardini, S. Arena, M. Orlandini, A. Scaloni, and A. Santucci. 2011. Surfome analysis of a wild-type wine Saccharomyces cerevisiae strain. Food Microbiol. 28:12201230.

Candela, M., S. Bergmann, M. Vici, B. Vitali, S. Turroni, B. J. Eikmanns, S. Hammerschmidt, and P. Brigidi. 2007. Binding of human plasminogen to Bifidobacterium. J. Bacteriol. 189:5929-5936.

Candela, M., E. Biagi, M. Centanni, S. Turroni, M. Vici, F. Musiani, B. Vitali, S. Bergmann, S. Hammerschmidt, and P. Brigidi. 2009. Bifidobacterial enolase, a cell surface receptor for human plasminogen involved in the interaction with the host. Microbiology 155:3294-3303.

Candela, M., M. Centanni, J. Fiori, E. Biagi, S. Turroni, C. Orrico, S. Bergmann, S. Hammerschmidt, and P. Brigidi. 2010. DnaK from
Bifidobacterium animalis ssp. lactis is a surface-exposed human plasminogen receptor upregulated in response to bile salts. Microbiology 156:1609-1618.

Cao, Y., and C. R. Bazemore-Walker. 2014. Proteomic profiling of the surface-exposed cell envelope proteins of Caulobacter crescentus. J. Proteomics 97:187-194.

Castro-Borges, W., A. Dowle, R. S. Curwen, J. Thomas-Oates, and R. A. Wilson. 2011. Enzymatic shaving of the tegument surface of live schistosomes for proteomic analysis: A rational approach to select vaccine candidates. PLoS Negl. Trop. Dis. 5:e993.

Danne, C., and S. Dramsi. 2012. Pili of gram-positive bacteria: roles in host colonization. Res. Microbiol. 163:645-658.

Desfossés-Foucault, E., V. Dussault-Lepage, C. Le Boucher, P. Savard, G. Lapointe, and D. Roy. 2012. Assessment of probiotic viability during cheddar cheese manufacture and ripening using propidium monoazide-PCR quantification. Front. Microbiol. 3:350.

Espino, E., K. Koskenniemi, L. Mato-Rodriguez, T. A. Nyman, J. Reunanen, J. Koponen, T. Ohman, P. Siljamaki, T. Alatossava, P. Varmanen, and K. Savijoki. 2015. Uncovering surface-exposed antigens of Lactobacillus rhamnosus by cell shaving proteomics and two-dimensional immunoblotting. J. Proteome Res. 14:1010-1024.

Fanning, S., L. J. Hall, M. Cronin, A. Zomer, J. MacSharry, D. Goulding, M. O. Motherway, F. Shanahan, K. Nally, G. Dougan, and D. van Sinderen. 2012a. Bifidobacterial surface-exopolysaccharide facilitates commensal-host interaction through immune modulation and pathogen protection. Proc. Natl. Acad. Sci. USA 109:21082113.

Fanning, S., L. J. Hall, and D. van Sinderen. 2012b. Bifidobacterium breve UCC2003 surface exopolysaccharide production is a beneficial trait mediating commensal-host interaction through immune modulation and pathogen protection. Gut Microbes 3:420-425.

Foroni, E., F. Serafini, D. Amidani, F. Turroni, F. He, F. Bottacini, M. O'Connell Motherway, A. Viappiani, Z. Zhang, C. Rivetti, D. van Sinderen, and M. Ventura. 2011. Genetic analysis and morphological identification of pilus-like structures in members of the genus Bifidobacterium. Microb. Cell Fact. 10(Suppl 1):S16.

Fujimoto, J., K. Tanigawa, Y. Kudo, H. Makino, and K. Watanabe. 2011. Identification and quantification of viable Bifidobacterium breve strain Yakult in human faeces by using strain-specific primers and propidium monoazide. J. Appl. Microbiol. 110:209-217.

Gilad, O., B. Svensson, A. H. Viborg, B. Stuer-Lauridsen, and S. Jacobsen. 2011a. The extracellular proteome of Bifidobacterium animalis ssp. lactis BB-12 reveals proteins with putative roles in probiotic effects. Proteomics 11:2503-2514.

Glenting, J., H. C. Beck, A. Vrang, H. Riemann, P. Ravn, A. M. Hansen, M. Antonsson, S. Ahrne, H. Israelsen, and S. Madsen. 2013. Anchorless surface associated glycolytic enzymes from Lactobacillus plantarum $299 \mathrm{v}$ bind to epithelial cells and extracellular matrix proteins. Microbiol. Res. 168:245-253.

González-Rodríguez, I., L. Ruiz, M. Gueimonde, A. Margolles, and B. Sanchez. 2013. Factors involved in the colonization and survival of bifidobacteria in the gastrointestinal tract. FEMS Microbiol. Lett. 340:1-10.

González-Rodríguez, I., B. Sanchez, L. Ruiz, F. Turroni, M. Ventura, P. Ruas-Madiedo, M. Gueimonde, and A. Margolles. 2012. Role of extracellular transaldolase from Bifidobacterium bifidum in mucin adhesion and aggregation. Appl. Environ. Microbiol. 78:3992-3998.

Granato, D., G. E. Bergonzelli, R. D. Pridmore, L. Marvin, M. Rouvet, and I. E. Corthesy-Theulaz. 2004. Cell surface-associated elongation factor Tu mediates the attachment of Lactobacillus johnsonii NCC533 (La1) to human intestinal cells and mucins. Infect. Immun. 72:2160-2169.

Guglielmetti, S., I. Tamagnini, D. Mora, M. Minuzzo, A. Scarafoni, S. Arioli, J. Hellman, M. Karp, and C. Parini. 2008. Implication of an outer surface lipoprotein in adhesion of Bifidobacterium bifidum to Caco-2 cells. Appl. Environ. Microbiol. 74:4695-4702.

Hammes, F., M. Berney, and T. Egli. 2011. Cultivation-independent assessment of bacterial viability. Pages 123-150 in High resolution microbial single cell analytics. Springer, New York, NY. 
Insenser, M. R., M. L. Hernaez, C. Nombela, M. Molina, G. Molero, and C. Gil. 2010. Gel and gel-free proteomics to identify Saccharomyces cerevisiae cell surface proteins. J. Proteomics 73:1183-1195.

Jiang, T., A. Mustapha, and D. A. Savaiano. 1996. Improvement of lactose digestion in humans by ingestion of unfermented milk containing Bifidobacterium longum. J. Dairy Sci. 79:750-757.

Juncker, A. S., H. Willenbrock, G. Von Heijne, S. Brunak, H. Nielsen, and A. Krogh. 2003. Prediction of lipoprotein signal peptides in gram-negative bacteria. Protein Sci. 12:1652-1662.

Kankainen, M., L. Paulin, S. Tynkkynen, I. von Ossowski, J. Reunanen, P. Partanen, R. Satokari, S. Vesterlund, A. P. Hendrickx, S. Lebeer, S. C. De Keersmaecker, J. Vanderleyden, T. Hamalainen, S. Laukkanen, N. Salovuori, J. Ritari, E. Alatalo, R. Korpela, T. Mattila-Sandholm, A. Lassig, K. Hatakka, K. T. Kinnunen, H. Karjalainen, M. Saxelin, K. Laakso, A. Surakka, A. Palva, T. Salusjarvi, P. Auvinen, and W. M. de Vos. 2009. Comparative genomic analysis of Lactobacillus rhamnosus GG reveals pili containing a human-mucus binding protein. Proc. Natl. Acad. Sci. USA 106:17193-17198.

Kline, K. A., K. W. Dodson, M. G. Caparon, and S. J. Hultgren. 2010. A tale of two pili: Assembly and function of pili in bacteria. Trends Microbiol. 18:224-232.

Konstantinov, S. R., H. Smidt, W. M. de Vos, S. C. Bruijns, S. K. Singh, F. Valence, D. Molle, S. Lortal, E. Altermann, T. R. Klaenhammer, and Y. van Kooyk. 2008. S layer protein A of Lactobacillus acidophilus NCFM regulates immature dendritic cell and T cell functions. Proc. Natl. Acad. Sci. USA 105:19474-19479.

Krogh, A., B. Larsson, G. von Heijne, and E. L. Sonnhammer. 2001. Predicting transmembrane protein topology with a hidden Markov model: Application to complete genomes. J. Mol. Biol. 305:567580.

Le Maréchal, C., V. Peton, C. Ple, C. Vroland, J. Jardin, V. BriardBion, G. Durant, V. Chuat, V. Loux, B. Foligne, S. M. Deutsch, H. Falentin, and G. Jan. 2015. Surface proteins of Propionibacterium freudenreichii are involved in its anti-inflammatory properties. J. Proteomics 113:447-461.

Lebeer, S., J. Vanderleyden, and S. C. De Keersmaecker. 2010. Host interactions of probiotic bacterial surface molecules: Comparison with commensals and pathogens. Nat. Rev. Microbiol. 8:171-184.

Lei, B., S. Mackie, S. Lukomski, and J. M. Musser. 2000. Identification and immunogenicity of group a Streptococcus culture supernatant proteins. Infect. Immun. 68:6807-6818.

Mandlik, A., A. Swierczynski, A. Das, and H. Ton-That. 2008. Pili in gram-positive bacteria: Assembly, involvement in colonization and biofilm development. Trends Microbiol. 16:33-40.

Marteau, P., P. Seksik, and R. Jian. 2002. Probiotics and intestinal health effects: A clinical perspective. Br. J. Nutr. 88(Suppl 1):S51S57.

Martini, M. C., E. C. Lerebours, W. J. Lin, S. K. Harlander, N. M. Berrada, J. M. Antoine, and D. A. Savaiano. 1991. Strains and species of lactic acid bacteria in fermented milks (yogurts): Effect on in vivo lactose digestion. Am. J. Clin. Nutr. 54:1041-1046.

Meyrand, M., A. Guillot, M. Goin, S. Furlan, J. Armalyte, S. Kulakauskas, N. G. Cortes-Perez, G. Thomas, S. Chat, and C. Pechoux. 2013a. Surface proteome analysis of a natural isolate of Lactococcus lactis reveals the presence of pili able to bind human intestinal epithelial cells. Mol. Cell. Proteomics 12:3935-3947.

Meyrand, M., A. Guillot, M. Goin, S. Furlan, J. Armalyte, S. Kulakauskas, N. G. Cortes-Perez, G. Thomas, S. Chat, C. Pechoux, V. Dupres, P. Hols, Y. F. Dufrene, G. Trugnan, and M. P. ChapotChartier. 2013b. Surface proteome analysis of a natural isolate of Lactococcus lactis reveals the presence of pili able to bind human intestinal epithelial cells. Mol. Cell. Proteomics 12:3935-3947.

O'Connell Motherway, M., A. Zomer, S. C. Leahy, J. Reunanen, F. Bottacini, M. J. Claesson, F. O'Brien, K. Flynn, P. G. Casey, J. A. Munoz, B. Kearney, A. M. Houston, C. O'Mahony, D. G. Higgins, F. Shanahan, A. Palva, W. M. de Vos, G. F. Fitzgerald, M. Ventura, P. W. O'Toole, and D. van Sinderen. 2011. Functional genome analysis of Bifidobacterium breve $\mathrm{UCC} 2003$ reveals type
IVb tight adherence (Tad) pili as an essential and conserved hostcolonization factor. Proc. Natl. Acad. Sci. USA 108:11217-11222.

Olaya-Abril, A., L. Gomez-Gascon, I. Jimenez-Munguia, I. Obando, and M. J. Rodriguez-Ortega. 2012. Another turn of the screw in shaving gram-positive bacteria: Optimization of proteomics surface protein identification in Streptococcus pneumoniae. J. Proteomics 75:3733-3746.

Olaya-Abril, A., I. Jimenez-Munguia, L. Gomez-Gascon, I. Obando, and M. J. Rodriguez-Ortega. 2013. Identification of potential new protein vaccine candidates through pan-surfomic analysis of pneumococcal clinical isolates from adults. PLoS ONE 8:e70365.

Olaya-Abril, A., I. Jimenez-Munguia, L. Gomez-Gascon, and M. J. Rodriguez-Ortega. 2014. Surfomics: Shaving live organisms for a fast proteomic identification of surface proteins. J. Proteomics 97:164-176.

Op den Camp, H. J., A. Oosterhof, and J. H. Veerkamp. 1985. Interaction of bifidobacterial lipoteichoic acid with human intestinal epithelial cells. Infect. Immun. 47:332-334.

Ouwehand, A. C., S. Salminen, and E. Isolauri. 2002. Probiotics: An overview of beneficial effects. Antonie van Leeuwenhoek 82:279289

Rappsilber, J., Y. Ishihama, and M. Mann. 2003. Stop and go extraction tips for matrix-assisted laser desorption/ionization, nanoelectrospray, and LC/MS sample pretreatment in proteomics. Anal. Chem. 75:663-670.

Rodríguez-Ortega, M. J., N. Norais, G. Bensi, S. Liberatori, S. Capo, M. Mora, M. Scarselli, F. Doro, G. Ferrari, I. Garaguso, T. Maggi, A. Neumann, A. Covre, J. L. Telford, and G. Grandi. 2006. Characterization and identification of vaccine candidate proteins through analysis of the group A Streptococcus surface proteome. Nat. Biotechnol. 24:191-197.

Sánchez, B., M.-C. Champomier-Vergès, P. Anglade, F. Baraige, C. G. De Los Reyes-Gavilán, A. Margolles, and M. Zagorec. 2008. A preliminary analysis of Bifidobacterium longum exported proteins by two-dimensional electrophoresis. J. Mol. Microbiol. Biotechnol. 14:74-79.

Sánchez, B., L. Ruiz, M. Gueimonde, P. Ruas-Madiedo, and A. Margolles. 2013. Adaptation of bifidobacteria to the gastrointestinal tract and functional consequences. Pharmacol. Res. 69:127-136.

Sánchez, B., M. C. Urdaci, and A. Margolles. 2010. Extracellular proteins secreted by probiotic bacteria as mediators of effects that promote mucosa-bacteria interactions. Microbiology 156:3232-3242.

Schell, M. A., M. Karmirantzou, B. Snel, D. Vilanova, B. Berger, G. Pessi, M. C. Zwahlen, F. Desiere, P. Bork, M. Delley, R. D. Pridmore, and F. Arigoni. 2002. The genome sequence of Bifidobacterium longum reflects its adaptation to the human gastrointestinal tract. Proc. Natl. Acad. Sci. USA 99:14422-14427.

Severin, A., E. Nickbarg, J. Wooters, S. A. Quazi, Y. V. Matsuka, E. Murphy, I. K. Moutsatsos, R. J. Zagursky, and S. B. Olmsted. 2007. Proteomic analysis and identification of Streptococcus pyogenes surface-associated proteins. J. Bacteriol. 189:1514-1522.

Shah, N. P. 2000. Effects of milk-derived bioactives: An overview. Br. J. Nutr. 84(Suppl 1):S3-S10.

Shiby, V. K., and H. N. Mishra. 2013. Fermented milks and milk products as functional foods - A review. Crit. Rev. Food Sci. Nutr. $53: 482-496$

Solis, N., M. R. Larsen, and S. J. Cordwell. 2010. Improved accuracy of cell surface shaving proteomics in Staphylococcus aureus using a false-positive control. Proteomics 10:2037-2049.

Van Gerven, N., M. Sleutel, F. Deboeck, H. De Greve, and J. P. Hernalsteens. 2009. Surface display of the receptor-binding domain of the F17a-G fimbrial adhesin through the autotransporter AIDA-I leads to permeability of bacterial cells. Microbiology 155:468-476.

Vialás, V., P. Perumal, D. Gutierrez, P. Ximenez-Embun, C. Nombela, C. Gil, and W. L. Chaffin. 2012. Cell surface shaving of Candida albicans biofilms, hyphae, and yeast form cells. Proteomics 12:2331-2339.

Villarreal, M. L., M. Padilha, A. D. Vieira, B. D. Franco, R. C. Martinez, and S. M. Saad. 2013. Advantageous direct quantification 
of viable closely related probiotics in petit-suisse cheeses under in vitro gastrointestinal conditions by propidium monoazide- $\mathrm{qPCR}$. PLoS ONE 8:e82102.

Walters, M. S., and H. L. Mobley. 2009. Identification of uropathogenic Escherichia coli surface proteins by shotgun proteomics. J. Microbiol. Methods 78:131-135.

Wang, L. Q., F. Zhao, F. Liu, and X. C. Meng. 2013. Live/dead state is not the factor influencing adhesion ability of Bifidobacterium animalis KLDS2.0603. J. Microbiol. 51:584-589.

Yan, F., H. Cao, T. L. Cover, R. Whitehead, M. K. Washington, and D. B. Polk. 2007a. Soluble proteins produced by probiotic bacteria regulate intestinal epithelial cell survival and growth. Gastroenterology 132:562-575.

Yan, F., H. Cao, T. L. Cover, R. Whitehead, M. K. Washington, and D. B. Polk. 2007b. Soluble proteins produced by probiotic bacteria regulate intestinal epithelial cell survival and growth. Gastroenterology 132:562-575.

Ye, J., L. Fang, H. Zheng, Y. Zhang, J. Chen, Z. Zhang, J. Wang, S. Li, R. Li, L. Bolund, and J. Wang. 2006. WEGO: A web tool for plotting GO annotations. Nucleic Acids Res. 34:W293-297.

Zhai, Z., F. P. Douillard, H. An, G. Wang, X. Guo, Y. Luo, and Y. Hao. 2013. Proteomic characterization of the acid tolerance response in Lactobacillus delbrueckii ssp. bulgaricus CAUH1 and functional identification of a novel acid stress-related transcriptional regulator Ldb0677. Environ Microbiol. 16:1524-1537.

Zhang, C. X., M. C. Creskey, T. D. Cyr, B. Brooks, H. Huang, F Pagotto, and M. Lin. 2013. Proteomic identification of Listeria monocytogenes surface-associated proteins. Proteomics 13:30403045 . 